\title{
Sexual foraging segregation in South American sea lions increases during the pre-breeding period in the Río de la Plata plume
}

\author{
M. Drago ${ }^{1, *}$, V. Franco-Trecu ${ }^{2}$, L. Zenteno ${ }^{3}$, D. Szteren ${ }^{4}$, E. A. Crespo ${ }^{5}$, \\ F. G. Riet Sapriza ${ }^{2,8}$, L. de Oliveira ${ }^{6}$, R. Machado ${ }^{6,7}$, P. Inchausti ${ }^{1}$, L. Cardona ${ }^{3}$ \\ ${ }^{1}$ Department of Ecology \& Evolution, Centro Universitario Regional Este (CURE), University of the Republic, \\ C/ Tacuarembó s/n, 20000 Maldonado, Uruguay
}

${ }^{2}$ Proyecto Pinnípedos, Sección Etología, Facultad de Ciencias, Universidad de la República, Iguá 4225, 11400 Montevideo, Uruguay ${ }^{3}$ IRBIO and Department of Animal Biology, Faculty of Biology, University of Barcelona, Av. Diagonal 645, 08028 Barcelona, Spain ${ }^{4}$ Dpto de Ecología y Evolución, Facultad de Ciencias, Universidad de la República, Iguá 4225, 11400 Montevideo, Uruguay

${ }^{5}$ Laboratory of Marine Mammals, Centro Nacional Patagonico (CENPAT-CONICET), and National University of Patagonia, Blvd. Brown 3600, 9120 Puerto Madryn, Chubut, Argentina

${ }^{6}$ Study Group of Aquatic Mammals of Rio Grande do Sul (GEMARS), Av. Tramandaí 976, RS 95625-000, Imbé, Brazil

${ }^{7}$ Laboratório de Sistemática e Ecologia de Aves e Mamíferos Marinhos (LabSMar), Departamento de Zoologia/IB, Universidade Federal do Rio Grande do Sul (UFRGS), Av. Bento Gonçalves 9500, RS 91509-900, Porto Alegres, Brazil

${ }^{8}$ Present address: Lab. de Ecología Molecular de Vertebrados Acuáticos (LEMVA), Departamento Ciencias Biológicas, Facultad de Ciencias, Universidad de los Andes, Carrera 1E No 18A - 10, Bogotá, Colombia

\begin{abstract}
Stable carbon and nitrogen isotopes in skin and bone of South American sea lions from Brazil and Uruguay were analysed to test the hypothesis that trophic overlap between the sexes is lower during the pre-breeding season than throughout the rest of the year. The isotopic values of skin and bone were used to infer the trophic relationships between the sexes during the pre-breeding period and year round, respectively. Prey species were also analysed to establish a baseline necessary for interpreting the stable isotope ratios of skin and bone. Standard ellipse areas, estimated using Bayesian inference in the SIBER routine of the SIAR package in R, suggested that males and females used a wide diversity of foraging strategies throughout the year and that no differences existed between the sexes. However, the diversity of foraging strategies was largely reduced during the pre-breeding period, with all the individuals of each sex adopting similar strategies, but with the two sexes differing considerably in stable isotope values and the ellipse areas of males and females not overlapping at all. Nevertheless, the results revealed a general increase in the consumption of pelagic prey by both sexes during the pre-breeding period. The progressive crowding of individuals in the areas surrounding the breeding rookeries during the pre-breeding period could lead to an increase in the local population density, which could explain the above reported changes.
\end{abstract}

KEY WORDS: Otaria flavescens $\cdot$ Sexual foraging segregation $\cdot$ Skin $\cdot$ Bone $\cdot$ Stable isotope Bayesian ellipses

Resale or republication not permitted without written consent of the publisher

\section{INTRODUCTION}

Understanding intersexual differences in behaviour has important implications for breeding biology and population ecology. Although sexual foraging segregation is a widespread behaviour in the animal kingdom, its underlying causes remain poorly understood (Wearmouth \& Sims 2008). Furthermore, although sex-related differences in habitat use or feeding strategies have been previously investigated in 
some marine mammal species, they have been less well documented in otariid species (Wearmouth \& Sims 2008).

Males and females of the same species often differ in foraging behaviour and diet for at least 4 nonmutually exclusive reasons. The reproductive decision hypothesis attributes sex differences to the differing trade-offs between foraging and other vital activities (e.g. predator avoidance, provisioning of young, mate acquisition) faced by individuals of each sex aiming to maximize their individual fitness (Clutton-Brock \& Parker 1992, Jormalainen et al. 2001). The niche divergence hypothesis is based on the fitness benefit of reducing intraspecific competition by individuals of each sex foraging in different locations and/or on different prey species (e.g. Clarke et al. 1998). The sexual size-dimorphism hypothesis predicts that differences in male and female energy requirements, based on differences in body size, can account for sex-specific foraging behaviour (CluttonBrock et al. 1987, Nagy 1987, Mysterud 2000). Finally, differences in body size may result in differences in access to trophic resources, which may lead to contrasting foraging behaviour and diet composition between the sexes (Le Boeuf et al. 2000, Beck et al. 2003a,b, 2007, Breed et al. 2006).

The keystone importance of body mass in understanding physiological and behavioural variation is well illustrated for sexually dimorphic, air-breathing, marine vertebrates that forage underwater because it largely determines the oxygen stores and the massspecific rate of metabolism (Miller \& Irving 1975, Kooyman 1989, Fowler et al. 2007). Thus, body size differences clearly influence diving skills in pinnipeds since adults of large-bodied species often exploit deep, benthic habitats, whereas those of smallbodied species typically forage in epipelagic habitats (Kooyman et al. 1981, Gentry et al. 1986, Costa 1993, Costa et al. 2004). Likewise, small-bodied females of strongly sexually dimorphic species often have a more pelagic diet than males throughout their life (Le Boeuf et al. 2000, Meynier et al. 2008).

The South American sea lion Otaria flavescens is a highly sexually dimorphic species, with adult males weighing about double $(300-350 \mathrm{~kg})$ that of adult females (Cappozzo \& Perrin 2009). The South American sea lion is often regarded as a benthic forager (Werner \& Campagna 1995, Thompson et al. 1998), although available evidence indicates that adults are able to forage both close to the seabed and in midwater (Werner \& Campagna 1995, Soto et al. 2006). As expected from differences in body mass, northern Patagonia sea lion males had been reported to ex- ploit benthic and deeper foraging grounds than females (Campagna et al. 2001, Drago et al. 2009a), although dissimilarities in foraging habits between the sexes have decreased in this area during the last decade (Drago et al. 2009b). Similar patterns have been reported from Uruguay, where adult males and females use similar habitats on an annual basis (Franco-Trecu et al. 2014). Nevertheless, there are reasons to believe that the foraging behavior and diet of the South American sea lion may differ between the sexes during the pre-breeding season.

During the breeding season South American sea lions, scattered along the southwestern Atlantic coast from southern Brazil to southern Argentina (Cappozzo \& Perrin 2009), aggregate in few isolated rookeries, resulting in a $2000 \mathrm{~km}$ gap between the 2 northernmost rookeries in Uruguay and its closest rookeries in northern Patagonia (Vaz-Ferreira 1982, Grandi et al. 2008). As a result, their local population density appears to be much higher during the prebreeding (November-December) and breeding (January-February) periods than during the rest of the year (Vaz-Ferreira 1982, Campagna 1985, Rosas et al. 1994). Considering that South American sea lion males may fast during the whole breeding period to defend their territory and mate (Vaz-Ferreira 1975, Campagna \& Le Boeuf 1988), local population density can attain high values during the pre-breeding season (Vaz-Ferreira 1982, Rosas et al. 1994). Furthermore, the energetic requirements of males and females may differ during the pre-breeding period from those during the rest of the year for 2 main reasons. On the one hand, females must wean the previous year's pup, put up with the high energetic demands of both late gestation and pup rearing during the first weeks when they do not feed, and provide lipid-rich milk to their pups (Campagna 1985, Oftedal et al. 1987, Campagna \& Le Boeuf 1988). On the other hand, males must accumulate resources to invest in reproductive endeavours that would maximise their reproductive success and to cope with prolonged fasting during the breeding season (VazFerreira 1975, Campagna \& Le Boeuf 1988). These concurrent energetic demands may lead to a finer niche partitioning between adults of both sexes during the pre-breeding period.

Stable isotope analysis is a method that is especially well suited to the assessment of temporal variation in trophic habits at different timescales, provided that tissue turnover rates are known, since tissues with different isotopic turnover rates integrate dietary information over different timescales (Dalerum \& Angerbjörn 2005). Thus, analysis of a small sample of 
predator tissues with differing isotopic turnover rates allows investigation of the animal's diet at different timescales (Dalerum \& Angerbjörn 2005). In marine mammals, whereas skin integrates dietary information over a couple of months (Kurle \& Worthy 2001, Alves-Stanley \& Worthy 2009), bone integrates information over several years (Hobson \& Clark 1992a, Riofrio-Lazo \& Aurioles-Gamboa 2013). Furthermore, the stable isotope values of the prey species consumed by South American sea lions in Río de la Plata plume and adjoining areas in the southwestern Atlantic indicate that changes in the $\delta^{13} \mathrm{C}$ values of the tissues should primarily reflect changes in the proportion of benthic and pelagic prey items in the diet, whereas changes in the $\delta^{15} \mathrm{~N}$ should be primarily linked to changes in trophic level (Bugoni et al. 2010, Vales et al. 2014).

Here we analyse the stable carbon and nitrogen isotopes of bone and skin samples from the South American sea lion to test 2 hypotheses: (1) the consumption of energy rich pelagic prey increases during the pre-breeding season (November and December) compared with the annual average; and (2) the trophic overlap between the sexes is lower during the pre-breeding season than during the rest of the year.

\section{MATERIALS AND METHODS}

\section{Sampling}

Although the South American sea lion is one of the most frequent pinniped species in southern Brazil that occurs mainly during winter, individuals found along the southern Brazilian coast are part of the breeding stock of Uruguayan rookeries (Rosas et al. 1994, Artico et al. 2010). Indeed, South American sea lions that breed in Uruguay typically disperse throughout the year in the open sea after the breeding season, in an area ranging from northern Argentina to southern Brazil (Vaz-Ferreira 1982, Rosas et al. 1994, Zenteno et al. 2013). Accordingly, bone samples were collected from both sexes of adult South American sea lions that were stranded dead along the coast of the Rio Grande do Sul state (southern Brazil) between 1998 and 2009 and along the Uruguayan coast between 2006 and 2012; skin samples were collected from both sexes of adult reproductive individuals arriving at Isla de Lobos (Uruguay) during the 2009 breeding season (Fig. 1).

Bone samples from Brazilian individuals (10 males and 4 females) were obtained from the skulls of the scientific collection of the Grupo de Estudos de Mamíferos Aquáticos do Rio Grande do Sul (GEMARS) at Imbé (Brazil), while those from Uruguayan individuals (6 males and 10 females) were obtained from the skulls of the scientific collection of the Museo Nacional de Historia Natural (MNHN) at Montevideo (Uruguay). Only adult specimens were considered to avoid any possible agerelated bias (Drago et al. 2009a). The age of all the 
sampled individuals was estimated by counting growth layers in the dentine of one of their canines (Laws 1952) and ranged from 9 to $15 \mathrm{yr}$ for males and from 7 to $13 \mathrm{yr}$ for females. Sex was determined based on external morphology (e.g. presence of bacullum bone in males) during sample collection and eventually assessed using secondary sexual characteristics of the skull following Crespo (1984). The bone sample from the skull of each individual that was used for the isotopic analysis consisted of a small fragment of turbinate bone taken throughout its entire thickness from the nasal cavity. This bone type was selected because it is easy to crush and its sampling does not damage the skull, allowing subsequent studies.

All skin samples were collected in early January from randomly chosen, physically mature sea lions of unknown age (12 males and 10 females). The skin samples were obtained using a biopsy dart (punch tip $5 \times 25 \mathrm{~mm}$ ) shot by means of a $\mathrm{CO}_{2}$ Dan-Inject Rifle (Børkop, Denmark). Although stable carbon and nitrogen isotope signals in skin do not vary across the body (Todd et al. 2010), all samples were collected from the lumbar region of each specimen.

Samples of prey species consumed by South American sea lions in Río de la Plata plume and adjoining areas (Naya et al. 2000, Riet Sapriza et al. 2013) were collected from northern Argentina and southern Brazil in 2009 to determine their stable carbon and nitrogen isotope values (see Table 1). Samples of prey were provided by local fishermen or collected on board by the staff of the Marine Mammal Laboratory (CENPAT-CONICET) and GEMARS. The stable carbon and nitrogen isotope values from some additional prey (see Table 1) were taken from Bugoni et al. (2010) and FrancoTrecu et al. (2013), after having ascertained that their prey data (i.e. tissue type analyzed, sample preparation procedure and sampling time and location) were appropriate in the context of the present study. All bone samples were cleaned and stored dry, whereas all samples of skin and prey were stored in a freezer at $-20^{\circ} \mathrm{C}$ until analysis.

\section{Stable isotope analysis}

Once in the laboratory, samples were thawed, dried in a stove at $60^{\circ} \mathrm{C}$ for $36 \mathrm{~h}$, and ground into a fine powder using a mortar and a pestle. Lipids were removed from each sample using a chloroform: methanol (2:1) solution (Bligh \& Dyer 1959) because lipids are depleted in ${ }^{13} \mathrm{C}$ compared with other mole- cules and variability in lipid content of samples may result in undesirable variability in $\delta^{13} \mathrm{C}$ values (DeNiro \& Epstein 1978). Nevertheless, as chemical lipid extraction may lead to unpredictable changes in $\delta^{15} \mathrm{~N}$ values due inter alia to the inadvertent removal of amino acids (Sotiropoulos et al. 2004, Ryan et al. 2012), we extracted lipids for carbon isotope analysis and used a non-extracted subsample for nitrogen determination. Furthermore, as bone samples contain a high concentration of inorganic carbon that may add undesirable variability to $\delta^{13} \mathrm{C}$ (Lorrain et al. 2003), they were previously treated by soaking in $0.5 \mathrm{~N} \mathrm{HCl}$ for $24 \mathrm{~h}$ to decarbonise them (Newsome et al. 2006). Since $\mathrm{HCl}$ treatment adversely affects $\delta^{15} \mathrm{~N}$ (Bunn et al. 1995), each sample was divided into 2 subsamples-one used for carbon analyses after decarbonation, and the other for nitrogen analyses without decarbonation.

Approximately $1 \mathrm{mg}$ of dried bone, $0.3 \mathrm{mg}$ of skin, and $0.3 \mathrm{mg}$ of white muscle from fish, pleon muscle from crustaceans and mantle from cephalopods were weighed into tin cups $(3.3 \times 5 \mathrm{~mm})$, combusted at $900^{\circ} \mathrm{C}$, and analyzed in a continuous flow isotope ratio mass spectrometer (Flash 1112 IRMS Delta C Series EA; Thermo Finnigan). Atropine was used as a system check for elemental analyses. Samples were processed at the Centres Cientifics i Tecnologics of the University of Barcelona.

Stable isotope abundances, expressed in delta $(\delta)$ notation, where the relative variations in stable isotope ratios are expressed in per mil (\%) deviations from predefined international standards, were calculated as:

$$
\delta^{j} \mathrm{X}=\left[\left({ }^{\mathrm{j} X} /{ }^{i} \mathrm{X}\right)_{\text {sample }} /\left({ }^{\mathrm{j} X} \mathrm{X}{ }^{\mathrm{i} X}\right)_{\text {standard }}\right]-1
$$

where ${ }^{\mathrm{I} X}$ is the heavier isotope $\left({ }^{13} \mathrm{C}\right.$ or $\left.{ }^{15} \mathrm{~N}\right)$, and ${ }^{\mathrm{i}} \mathrm{X}$ is the lighter isotope $\left({ }^{12} \mathrm{C}\right.$ or $\left.{ }^{14} \mathrm{~N}\right)$ in the analytical sample and in the international measurement standard (Bond \& Hobson 2012); reference standards were the Vienna Pee Dee Belemnite (VPDB) calcium carbonate for $\delta^{13} \mathrm{C}$ and atmospheric nitrogen (air) for $\delta^{15} \mathrm{~N}$. Secondary isotopic reference materials of known ${ }^{13} \mathrm{C} /{ }^{12} \mathrm{C}$ ratios, as given by the International Atomic Energy Agency (IAEA, Vienna, Austria), were used for calibration at a precision of $0.2 \%$. These include polyethylene (IAEA $\mathrm{CH}_{7}, \delta^{13} \mathrm{C}$ $=-31.8 \%$ ), graphite $\left(\right.$ IAEA USGS ${ }_{24}, \delta^{13} \mathrm{C}=-16.1 \%$ ) and sucrose (IAEA $\mathrm{CH}_{6}, \delta^{13} \mathrm{C}=-10.4 \%$ ). For nitrogen, secondary isotopic reference materials of known ${ }^{15} \mathrm{~N} /{ }^{14} \mathrm{~N}$ ratios, namely $\left(\mathrm{NH}_{4}\right)_{2} \mathrm{SO}_{4}$ (IAEA $\mathrm{N}_{1}$, $\delta^{15} \mathrm{~N}=+0.4 \%$ and IAEA $\mathrm{N}_{2}, \delta^{15} \mathrm{~N}=+20.3 \%$ ) and $\mathrm{KNO}_{3}\left(\right.$ IAEA $\mathrm{NO}_{3}, \delta^{15} \mathrm{~N}=+4.7 \%$ ), were used to a precision of $0.3 \%$. 


\section{Data analyses}

We compared the stable isotope values $\left(\delta^{13} \mathrm{C}\right.$ and $\delta^{15} \mathrm{~N}$ ) of prey species among regions (southern Brazil, Uruguay and northern Argentina) using a nested ANOVA, with prey species nested within regions. Two-way ANOVA was used to investigate the differences in bone $\delta^{13} \mathrm{C}$ and $\delta^{15} \mathrm{~N}$ values between the sexes and between Brazil and Uruguay. Student's $t$ test was used to detect differences in skin $\delta^{13} \mathrm{C}$ and $\delta^{15} \mathrm{~N}$ values between males and females from Uruguay.

Tissue-specific prey-to-predator isotopic discrimination factors need to be known to relate stable isotope ratios in the predator to those in its diet (Hobson \& Clark 1992b, Bocherens et al. 2014). The prey-topredator isotopic discrimination factor in skin has been determined for several pinniped species in captivity (Hobson et al. 1996), and the prey-to-predator isotopic discrimination factor in bone has been assessed indirectly for the South American sea lion by Zenteno et al. (2015). While Hobson et al. (1996) reported a prey-to-predator isotopic discrimination factor of $+2.3 \%$ or $\delta^{15} \mathrm{~N}$ and $+2.8 \%$ o for $\delta^{13} \mathrm{C}$ in skin, Zenteno et al. (2015) found the isotopic discrimination factor of the South American sea lion bone to be $+4.4 \pm 0.8 \%$ for $\delta^{15} \mathrm{~N}$ and $+3.5 \pm 0.8 \%$ for $\delta^{13} \mathrm{C}$. Accordingly, stable isotope values in bone and skin were used to calculate the expected stable isotope values in the diet of sea lions throughout the year and during the pre-breeding season, respectively. To do so, the corresponding prey-to-predator isotopic discrimination factors were subtracted from the stable isotope values of bone and skin and means were compared using 2-way ANOVA. We checked the normality of the isotopic values and the homogeneity of variances among groups using Lilliefors test and Levene's test prior to any analyses. Data are always shown as means \pm SDs, unless otherwise stated. All analyses were carried out using SPSS 15.

We estimated the population isotopic niche width using the convex hull area in the isotopic space defined by $\delta^{13} \mathrm{C}$ and $\delta^{15} \mathrm{~N}$ (Layman et al. 2007). Nonetheless, the use of Euclidean methods (e.g. convex hulls) to define the isotopic niche space of a species in a community (Layman et al. 2007) is subject to sampling biases and is sensitive to sample size (Jackson et al. 2011). The standard ellipse areas estimated by Bayesian inference can incorporate uncertainties such as sampling biases and small sample sizes into niche metrics (Jackson et al. 2011). Thus, we estimated the width of the isotopic niche at the population level using the Bayesian standard ellipse area
$\left(\mathrm{SEA}_{\mathrm{B}}\right)$ in the function SIBER (Stable Isotope Bayesian Ellipses in $\mathrm{R}_{i}$ Jackson et al. 2011) of the library SIAR (Stable Isotope Analysis in $\mathrm{R}_{\text {; }}$ Parnell et al. 2010) in the software $R$ (R Core Team 2013). Furthermore, we calculated the magnitude of the isotopic overlap between the sexes at the beginning of the pre-breeding season (skin values) and year round (bone values) based on 100000 posterior draws of the standard ellipse areas corrected for small sample size $\left(\mathrm{SEA}_{\mathrm{C}}\right)$ parameters (Jackson et al. 2011). This approach, which is based on MarkovChain Monte Carlo (MCMC) simulation, assigns measures of uncertainty to construct parameters of ellipses in a way similar to a bootstrap.

\section{RESULTS}

Table 1 shows the stable carbon and nitrogen isotope values of the South American sea lion and their prey off southern Brazil, Uruguay and northern Argentina. We found that the prey of the South American sea lion differed statistically in their $\delta^{13} \mathrm{C}$ and $\delta^{15} \mathrm{~N}$ values (nested ANOVA; $\delta^{13} \mathrm{C}_{\text {model }}: F_{39,205}=$ $34.752, \mathrm{p}<0.001, R_{\text {corrected }}^{2}=0.865 ; \delta^{15} \mathrm{~N}_{\text {model }}: F_{39,205}=$ $\left.57.408, \mathrm{p}<0.001, R_{\text {corrected }}^{2}=0.915\right)$, both among species (nested ANOVA; $\delta^{13} \mathrm{C}_{\text {species: }}: F_{37,205}=31.780, \mathrm{p}<$ $\left.0.001 ; \delta^{15} \mathrm{~N}_{\text {species }}: F_{37,205}=51.211, \mathrm{p}<0.001\right)$ and regions (nested ANOVA; $\delta^{13} C_{\text {regions }}: F_{2,205}=54.329$, $\left.\mathrm{p}<0.001 ; \delta^{15} \mathrm{~N}_{\text {regions }}: F_{2,205}=114.477, \mathrm{p}<0.001\right)$. This was because pelagic prey were usually depleted in ${ }^{13} \mathrm{C}$ when compared with demersal prey from the same region, small pelagic fishes were depleted in ${ }^{15} \mathrm{~N}$ when compared with medium pelagic fishes and demersal fishes from the same region, and fishes and cephalopods from northern Argentina were usually enriched in ${ }^{15} \mathrm{~N}$ when compared with similar species from Uruguay and southern Brazil (Fig. 2).

Adult male and female sea lions did not differ in their bone stable isotope values, with differences between Brazil and Uruguay being statistically nonsignificant (2-way ANOVA; $\delta^{13} \mathrm{C}_{\text {model }}: F_{3,29}=0.606$, $\mathrm{p}=0.617 ; \delta^{15} \mathrm{~N}_{\text {model }}: F_{3,29}=2.613, \mathrm{p}=0.073$ ). Accordingly, adult male and female sea lions had similar diets on an annual basis. Conversely, adult male and female sea lions sampled at the beginning of the breeding season differed significantly in their skin isotope values (Student's $t$-test; $\delta^{13} \mathrm{C}: t_{20}=3.072, \mathrm{p}=$ $0.006 ; \delta^{15} \mathrm{~N}: t_{20}=11.634, \mathrm{p}<0.001$ ), thus revealing different diets during the pre-breeding period.

Since sea lions from Brazil and Uruguay did not differ in bone stable isotope values, data from individuals of the same sex were pooled for further analyses. 
Table 1. Stable isotope values (mean $\pm \mathrm{SD}$ ) of the South American sea lion Otaria flavescens and their prey off southern Brazil, Uruguay and northern Argentina. $\mathrm{n}$ (non-bold): sample size; $\mathrm{n}$ (bold): number of species; bold isotopic values: gross mean of the prey species by trophic guild. ${ }^{a}$ Source: Bugoni et al. (2010) ${ }_{i}^{\text {b }}$ Source: Franco-Trecu et al. (2013)

\begin{tabular}{|c|c|c|c|c|}
\hline Scientific name & Common name & $\mathrm{n}$ & $\delta^{13} \mathrm{C}(\%)$ & $\delta^{15} \mathrm{~N}(\%)$ \\
\hline \multicolumn{5}{|l|}{ Southern Brazil } \\
\hline \multicolumn{5}{|l|}{ Medium pelagic fish } \\
\hline Pomatomus saltatrix & Bluefish & 5 & $-16.6 \pm 0.5$ & $18.6 \pm 0.7$ \\
\hline Trichiurus lepturus & Cutlassfish & 5 & $-15.7 \pm 0.3$ & $16.6 \pm 0.5$ \\
\hline Cynoscion guatucupa & Stripped weakfish & 5 & $-16.5 \pm 0.7$ & $16.0 \pm 0.6$ \\
\hline Macrodon atricauda & King weakfish & 5 & $-14.5 \pm 0.6$ & $17.0 \pm 0.3$ \\
\hline \multirow{2}{*}{ Trachurus lathami ${ }^{\mathrm{a}}$} & Rough scad & 9 & $-16.1 \pm 0.1$ & $16.1 \pm 1.1$ \\
\hline & & 5 & $-15.9 \pm 0.8$ & $16.9 \pm 1.1$ \\
\hline \multicolumn{5}{|l|}{ Small pelagic fish } \\
\hline Engraulis anchoita $^{\mathrm{a}}$ & Argentine anchovy & 14 & $-16.5 \pm 0.5$ & $14.7 \pm 0.5$ \\
\hline \multirow[t]{2}{*}{ Sardinella brasiliensis ${ }^{a}$} & Brazilian sardine & 7 & $-17.6 \pm 0.6$ & $11.4 \pm 1.0$ \\
\hline & & 2 & $-17.1 \pm 0.8$ & $13.1 \pm 2.3$ \\
\hline \multicolumn{5}{|l|}{ Demersal fish } \\
\hline Menticirrhus americanus & Southern kingfish & 5 & $-15.4 \pm 0.5$ & $16.0 \pm 0.5$ \\
\hline Micropogonias furnieri & White croacker & 5 & $-15.7 \pm 0.6$ & $15.3 \pm 0.4$ \\
\hline Umbrina canosai $^{\mathrm{a}}$ & Argentine croaker & 10 & $-15.5 \pm 0.3$ & $16.6 \pm 0.8$ \\
\hline \multirow[t]{2}{*}{ Urophycis brasiliensis $^{\mathrm{a}}$} & Brazilian codling & 11 & $-15.6 \pm 0.5$ & $16.5 \pm 0.7$ \\
\hline & & 4 & $-15.6 \pm 0.1$ & $16.1 \pm 0.6$ \\
\hline \multicolumn{5}{|l|}{ Pelagic cephalopods } \\
\hline Illex argentinus & Argentine short-finned squid & 5 & $-18.1 \pm 0.2$ & $10.0 \pm 0.5$ \\
\hline \multirow[t]{2}{*}{ Loligo paelei } & Atlantic longfin squid & 5 & $-17.6 \pm 0.2$ & $11.3 \pm 0.5$ \\
\hline & & 2 & $-17.9 \pm 0.4$ & $10.7 \pm 0.9$ \\
\hline Loligo sanpaulensis & Brazilian squid & 5 & $-16.3 \pm 0.1$ & $15.2 \pm 0.3$ \\
\hline Sea lion & & & & \\
\hline Otaria flavescens ( $0^{7}$ Bone) & South American sea lion & 10 & $-12.1 \pm 0.7$ & $20.5 \pm 0.4$ \\
\hline Otaria flavescens (o Bone) & South American sea lion & 4 & $-12.0 \pm 0.3$ & $20.4 \pm 0.3$ \\
\hline Uruguay & & & & \\
\hline Medium pelagic fish & & & & \\
\hline Cynoscion guatucupa ${ }^{\mathrm{b}}$ & Stripped weakfish & 6 & $-15.4 \pm 0.3$ & $17.0 \pm 0.1$ \\
\hline Trichiurus lepturus ${ }^{\mathrm{b}}$ & Cutlassfish & 2 & $-17.3 \pm 0.4$ & $15.4 \pm 1.4$ \\
\hline Macrodon atricauda ${ }^{\mathrm{b}}$ & King weakfish & 10 & $-15.3 \pm 0.3$ & $16.3 \pm 0.2$ \\
\hline Merluccius hubbsi $(>30 \mathrm{~cm})^{\mathrm{b}}$ & Argentine hake & 1 & -16.2 & 17.9 \\
\hline & & 4 & $-16.0 \pm 0.9$ & $16.6 \pm 1.1$ \\
\hline Small pelagic fish & & & & \\
\hline Engraulis anchoita ${ }^{\mathrm{b}}$ & Argentine anchovy & 6 & $-18.5 \pm 0.3$ & $14.2 \pm 1.0$ \\
\hline Demersal fish & & & & \\
\hline Micropogonias furnieri ${ }^{\mathrm{b}}$ & White croacker & 7 & $-14.9 \pm 0.1$ & $16.2 \pm 0.1$ \\
\hline Umbrina canosai ${ }^{\mathrm{b}}$ & Argentine croaker & 1 & -16.0 & 15.7 \\
\hline Urophycis brasiliensis $^{\mathrm{b}}$ & Brazilian codling & 8 & $-15.0 \pm 0.7$ & $16.6 \pm 0.7$ \\
\hline & & 3 & $-15.3 \pm 0.6$ & $16.2 \pm 0.5$ \\
\hline Demersal crustaceans & & & & \\
\hline Pleoticus muellieri ${ }^{\mathrm{b}}$ & Red shrimp & 4 & $-16.0 \pm 0.3$ & $13.9 \pm 0.2$ \\
\hline Pelagic cephalopods & & & & \\
\hline Loligo sanpaulensis & Brazilian squid & 2 & $-17.9 \pm 0.1$ & $13.7 \pm 0.2$ \\
\hline Illex argentinus ${ }^{\mathrm{b}}$ & Argentine short-finned squid & 2 & $-18.7 \pm 0.2$ & $13.9 \pm 0.7$ \\
\hline Sea lion & & & & \\
\hline Otaria flavescens (ơ Skin) & South American sea lion & 12 & $-13.9 \pm 0.2$ & $21.9 \pm 0.4$ \\
\hline Otaria flavescens (o Skin) & South American sea lion & 10 & $-14.2 \pm 0.2$ & $19.8 \pm 0.4$ \\
\hline Otaria flavescens ( $0^{\prime \prime}$ Bone) & South American sea lion & 6 & $-12.4 \pm 0.6$ & $21.6 \pm 0.5$ \\
\hline Otaria flavescens (o Bone) & South American sea lion & 10 & $-12.4 \pm 0.9$ & $20.5 \pm 1.4$ \\
\hline Northern Argentina & & & & \\
\hline Medium pelagic fish & & & & \\
\hline Merluccius hubbsi (>30 cm) & Argentine hake & 3 & $-18.0 \pm 0.5$ & $15.6 \pm 0.4$ \\
\hline Trachurus picturatus & Blue jack mackerel & 5 & $-17.6 \pm 0.3$ & $16.9 \pm 0.5$ \\
\hline Stromateus brasiliensis & Butterfish & 5 & $-16.9 \pm 0.6$ & $17.4 \pm 0.4$ \\
\hline Cynoscion guatucupa & Stripped weakfish & 5 & $-17.2 \pm 0.2$ & $17.6 \pm 0.3$ \\
\hline & & 4 & $-17.4 \pm 0.5$ & $16.9 \pm 0.9$ \\
\hline Small pelagic fish & & & & \\
\hline Engraulis anchoita & Argentine anchovy & 5 & $-18.2 \pm 0.3$ & $15.5 \pm 0.5$ \\
\hline Sorgentinia incisa & Silverside & 5 & $-17.6 \pm 0.3$ & $15.5 \pm 0.2$ \\
\hline Merluccius hubbsi $(<30 \mathrm{~cm})$ & Argentine hake & 2 & $-18.4 \pm 0.1$ & $14.8 \pm 0.1$ \\
\hline & & 3 & $-18.1 \pm 0.4$ & $15.3 \pm 0.4$ \\
\hline Demersal fish & & & & \\
\hline Menticirrhus americanus & Southern kingfish & 5 & $-15.0 \pm 0.9$ & $19.1 \pm 1.1$ \\
\hline Micropogonias furnieri & White croacker & 5 & $-16.0 \pm 0.3$ & $16.7 \pm 0.5$ \\
\hline Paralichthys isosceles & Flounder & 5 & $-16.6 \pm 0.2$ & $17.7 \pm 0.2$ \\
\hline Prionotus nudigula & Bluewing searobin & 5 & $-17.0 \pm 0.1$ & $18.0 \pm 0.6$ \\
\hline Raneya brasiliensis & Banded cusk-eel & 5 & $-16.2 \pm 0.4$ & $17.4 \pm 0.6$ \\
\hline & & 5 & $-16.0 \pm 0.7$ & $17.8 \pm 0.9$ \\
\hline Demersal crustaceans & & & & \\
\hline Pleoticus muelleri & Red shrimp & 1 & -16.4 & 14.4 \\
\hline Pelagic cephalopods & & & & \\
\hline Loligo sanpaulensis & Brazilian squid & 5 & $-16.7 \pm 0.2$ & $18.6 \pm 0.2$ \\
\hline Illex argentinus & Argentine short-finned squid & 5 & $-17.5 \pm 0.4$ & $14.7 \pm 0.5$ \\
\hline
\end{tabular}



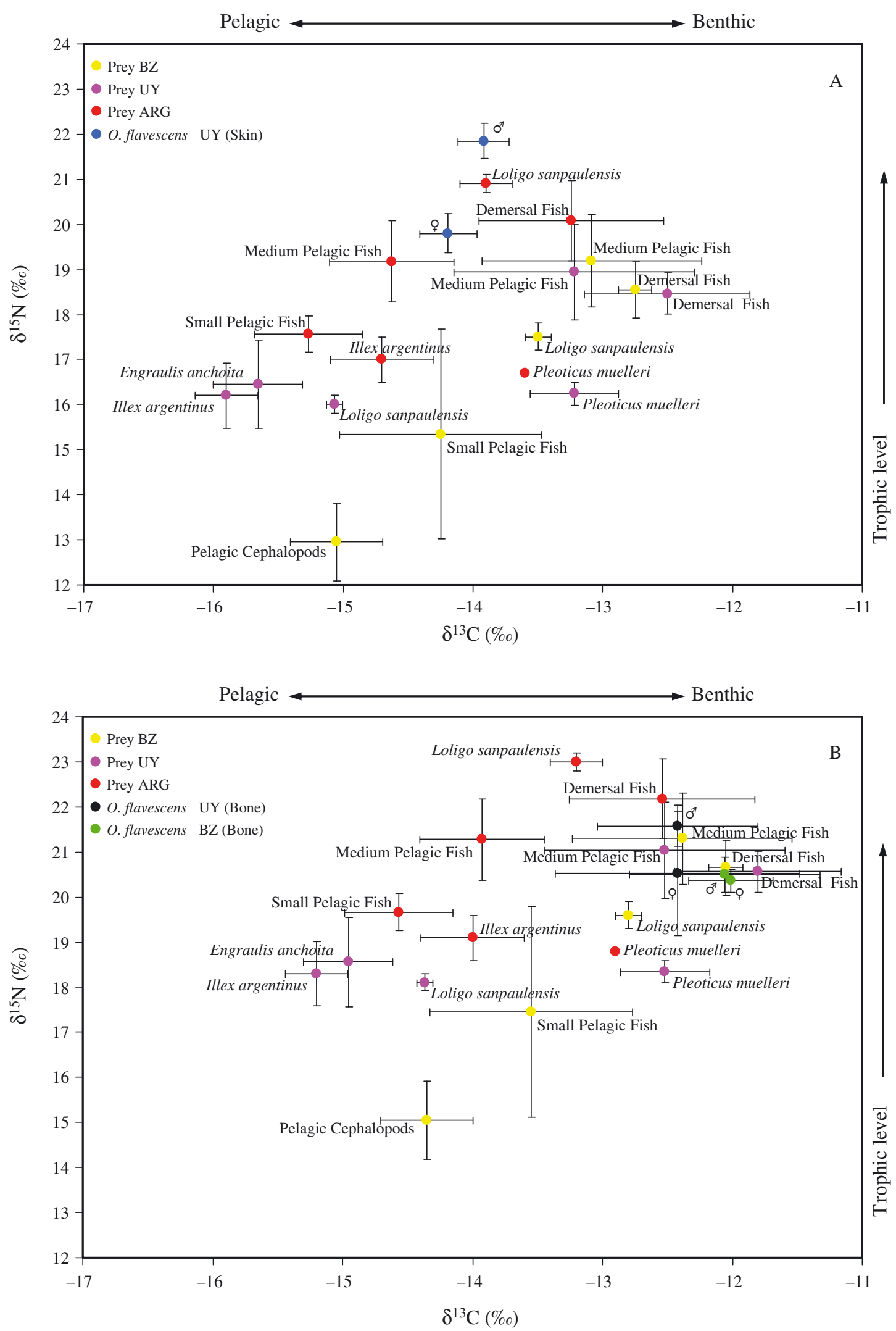

Fig. 2. Bivariate stable isotope values (mean $\pm \mathrm{SD}$ ) of South American sea lions Otaria flavescens from southern Brazil and Uruguay (A) during the pre-breeding period (skin values) and (B) year round (bone values) and values expected if diet was based on a single prey or group of prey. Stable isotope values for expected diets (BZ: southern Brazil; UY: Uruguay; ARG: northern Argentina) differ between panels because of differences in the prey-to-predator discrimination factors of skin and bone (see original data and sample size in Table 1) 
Statistically significant differences were found when the expected $\delta^{13} \mathrm{C}$ values of the diet consumed by males and females during the pre-breeding period were compared with that consumed on an annual basis (2-way ANOVA; $\delta^{13} \mathrm{C}_{\text {model }}: F_{3,51}=14.854, \mathrm{p}<$
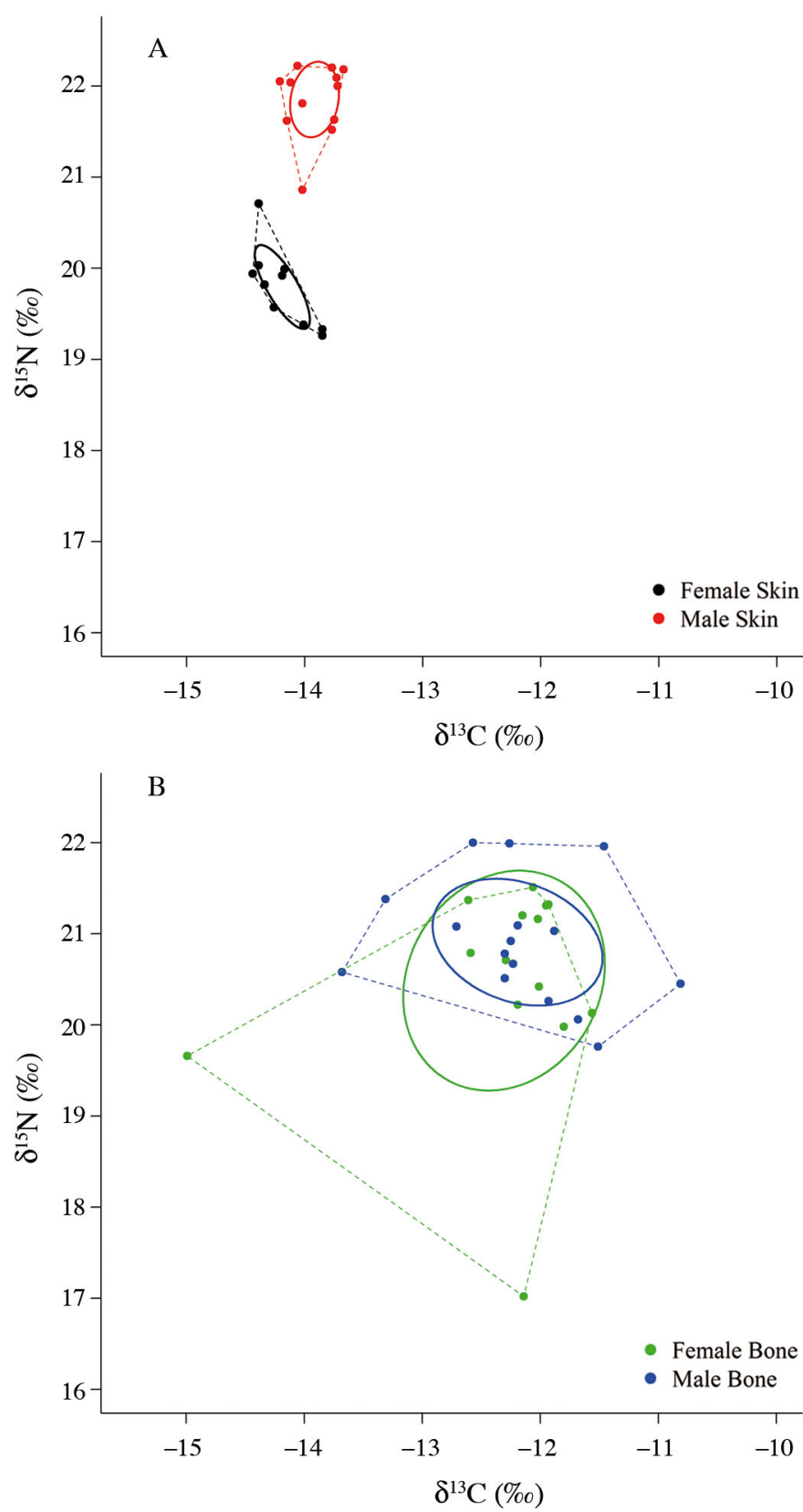

Fig. 3. Bayesian standard ellipse areas (solid lines) and their respective convex hulls (dashed lines) for South American sea lion Otaria flavescens (A) during the pre-breeding period (skin values) and (B) year round (bone values), calculated by SIBER using the bivariated isotopic values (solid circles) of each male and female. Stable isotope values for skin and bone of sea lions were not corrected for prey-topredator isotopic discrimination
$0.001, R_{\text {corrected }}^{2} 0.449$ ). However, these differences were statistically significant only between the prebreeding and the annual diet (2-way ANOVA; $\delta^{13} C_{\text {period: }}: F_{1,51}=43.581, \mathrm{p}<0.001$ ), without any difference between the sexes (2-way ANOVA; $\delta^{13} \mathrm{C}_{\text {sex }}$ : $F_{1,51}=1.283, \mathrm{p}=0.263$ ) and with a nonsignificant interaction term (2-way ANOVA; $\delta^{13} C_{\text {interaction: }} F_{1,51}=$ $0.248, \mathrm{p}=0.621$ ).

Statistically significant differences were also found for the expected $\delta^{15} \mathrm{~N}$ values of the diet consumed by males and females during the pre-breeding period and that consumed on an annual basis (2-way ANOVA; $\delta^{15} \mathrm{~N}_{\text {model }}: F_{3,51}=52.864, \mathrm{p}<0.001, R_{\text {corrected }}^{2}$ $=0.753$ ). There were significant differences between periods (2-way ANOVA; $\delta^{15} \mathrm{~N}_{\text {period }}: F_{1,51}=107.660, \mathrm{p}$ $<0.001$ ), and between the sexes (2-way ANOVA; $\left.\delta^{15} \mathrm{~N}_{\text {sex }}: F_{1,51}=33.818, \mathrm{p}<0.001\right)$. The interaction term was also significant (2-way ANOVA; $\delta^{15} \mathrm{~N}_{\text {interaction: }}$ $\left.F_{1,51}=14.382, \mathrm{p}<0.001\right)$ because differences between the sexes were significant only during the prebreeding period (Fig. 2).

The Bayesian ellipse of females was larger and encompassed that of males when bone data were considered (Fig. 3). The overlap area represented $44.89 \%$ of the surface of the female ellipse and $96.0 \%$ of the surface of the male ellipse. However, the Bayesian ellipses of males and females had similar areas and did not overlap at all when skin data were considered (Fig. 3). Furthermore, the surface of the Bayesian ellipses based on the skin data was smaller than that based on bone data (female $\mathrm{SEA}_{\mathrm{B}(\text { bone })}$ mean $=3.33 \%^{2}, 95 \%$ credibility interval of 1.78 to $5.08 \%{ }^{2}$; female $\mathrm{SEA}_{\mathrm{B}(\mathrm{skin})}$ mean $=0.92 \%{ }^{2}$, $95 \%$ credibility interval of 0.46 to $0.98 \%{ }^{2}$; male $\mathrm{SEA}_{\mathrm{B}(\text { bone) }}$ mean $=1.76 \%^{2}, 95 \%$ credibility interval of 0.98 to $2.65 \%^{2}$; male $\mathrm{SEA} \mathrm{B}_{\mathrm{B}(\mathrm{skin})}$ mean $=0.86 \%^{2}{ }^{2}, 95 \%$ credibility interval of 0.44 to $1.38 \%^{2}$ ).

\section{DISCUSSION}

Stable isotope analysis has become a standard tool for investigating trophic relationships of wild animals (Newsome et al. 2010, Layman et al. 2012). Their use is based on 3 main assumptions: (1) stable carbon and nitrogen isotopes in the body of an animal come directly from its food; consequently, the stable isotope ratios in their tissues can be used to assess the relative importance of potential prey that differ in stable isotope ratios (DeNiro \& Epstein 1978, 1981); (2) the assimilated organic matter is enriched in the heavy isotopes of both carbon and nitrogen when passed from one trophic level to the next, although 
that enrichment is greater for nitrogen than for carbon (Michener \& Schell 1994); and (3) the rate of change of the stable isotope ratio in each tissue depends on its metabolic rate; hence, the reference time of dietary information is tissue-dependent (Michener \& Schell 1994).

Neither prey-to-predator isotopic discrimination factors nor tissue turnover have been determined for the South American sea lion in controlled experiments; thus, extrapolation from studies conducted on phylogenetically close species is required (e.g. Hückstädt et al. 2007, Drago et al. 2010, Vales et al. 2014). We have used this approach to compute the expected stable isotope values of the diet of the South American sea lions as indicated by stable isotope values in skin and bone, considering that the direct comparison of the stable isotope values from tissues differing in discrimination factors may lead to major mistakes (Bocherens et al. 2014). Nevertheless, caution is needed and all the results should be considered as an approximation due to the multiple assumptions involved.

In this context, the reported differences between the sexes in terms of the expected diet stable isotope ratios revealed the preferential consumption of pelagic prey over benthic prey during the pre-breeding period, whereas the opposite was true throughout the year (Fig. 2). This suggests a dietary shift, favouring species with higher energy density, immediately before the onset of the breeding season (Eder \& Lewis 2005, Drago et al. 2009b).

The energy density of prey plays a central role in the foraging ecology of at least some otariids (Rosen \& Trites 2000, Staniland et al. 2007). The dietary shift observed during the pre-breeding period is consistent with a foraging strategy aiming to maximize energy intake, if energy density was the only criterion for prey selection during key foraging periods with higher energetic demands. Such a dietary shift would allow individuals of both sexes to increase their energy reserves immediately before the onset of breeding, but only if the increased travel cost did not reduce the benefit of preying on offshore pelagic prey with higher energy density (Costa 2008). Our result is congruent with similar findings for the South American sea lions breeding in northern Patagonia, although detailed information about patterns of habitat use during the breeding season have been reported only for females (Drago et al. 2010) and almost nothing is known about males (Campagna et al. 2001). Furthermore, evidence supporting the hypothesis of a general decline in the nutritional quality of the diet after the perinatal period also comes from studies on milk quality, as the fat content and, therefore, also the energy content of the milk of female South American sea lions was found to decrease after parturition and to increase several months later, just prior to weaning (Werner et al. 1996).

In addition, the isotopic bone data presented here indicate that both males and females sampled in southern Brazil and Uruguay were trophically very similar, since sea lions from the 2 sites did not differ in bone stable isotope values (Fig. 2). Considering that the slow isotopic turnover rate of bone tissue allows integration of the different isotopic values of prey of both ecosystems, this similarity suggests that these animals feed in similar areas and/or share prey species when considering the diet consumed year round. This is probably because sea lions breeding in Uruguay apparently scatter in the open sea from Uruguay to southern Brazil, searching for food after the end of the breeding season (Rosas et al. 1994).

The Bayesian ellipses suggest that male and female sea lions used a wide diversity of foraging strategies throughout the year and that no differences existed between the sexes (Fig. 3). Furthermore, despite the larger body size (hence, larger diving and breath-holding capacity) of male South American sea lions, the diversity of foraging strategies was wider in females. While the latter could result from the influence of a few potential outliers, we think that these extreme points are more likely to reflect the individual trophic specialisation reported for the Uruguayan South American sea lion population (Franco-Trecu et al. 2014). The diversity in the female foraging tactics could reflect the consumption of prey at lower trophic levels and/or the exploitation of more pelagic habitats compared to males, as a means to decrease the intrapopulation niche overlap. Similar to our results with bone tissue, the stable isotope contents of South American sea lion whiskers (that integrate up to 2 or 3 yr of foraging) showed a large overlap of the isotopic niches between the sexes and that females had wider niches than males (Franco-Trecu et al. 2014).

The diversity of foraging strategies was strongly reduced in both sexes during the pre-breeding period, since all individuals increased their consumption of pelagic prey. However, the skin stable isotope values of both sexes differed significantly, with the area covered by the Bayesian ellipses being sharply reduced and the ellipses of males and females not overlapping at all (Figs. $2 \& 3$ ).

During the pre-breeding period, the progressive crowding of individuals in the areas surrounding the 
breeding rookeries could lead to an increase in the local population density and, therefore, to an overall decrease in the per capita resource share. Sea lion males might also be more efficient foragers than females during key foraging periods, provided that their larger size and physiological abilities enable them to have easier access (capture and handle) to larger and more energetically rewarding prey than females (Page et al. 2005). Thus, considering the isotopic landscape of Río de la Plata plume and adjoining areas (Fig. 2), the per capita consumption of larger pelagic prey at higher trophic levels by male sea lions could be expected to increase during the pre-breeding period, when intraspecific competition between the sexes is stronger due to the concomitant increase in local population density and the necessity to maximize fitness during a period of high energetic demands. This is supported by the significantly higher trophic level of the male diet than that of females during the pre-breeding season, and by the increase in pelagic prey size in accordance with the increase in the trophic level (Figs. 2 \& 3). Trophic segregation at this time of year may provide a means of reducing intraspecific competition related to high niche overlap, while permitting males to access higher quality foods needed to face the energetic demands during the breeding period (Beck et al. 2007).

In summary, our results support the niche divergence hypothesis as the most likely explanation for the trophic segregation between the sexes of the South American sea lion. However, this segregation only takes place during the pre-breeding season, when crowding in the areas surrounding the breeding rookeries increases and per-capita resource share declines. Intersexual differences largely vanish during the rest of the year, since individuals of both sexes spread over a huge area and increase both their dietary niche breadth and niche overlap (Fig. 3). This suggests that individual South American sea lions of both sexes could exploit a greater range of habitats and prey when they are more scattered and intraspecific competition is expected to decrease.

Acknowledgements. We thank the staff of the Grupo de Estudos de Mamíferos Aquáticos do Rio Grande do Sul (GEMARS, Brazil) and the Museo Nacional de Historia Natural (MNHN, Uruguay) for allowing access to their scientific collection, and the staff of the Marine Mammal Laboratory of the Centro Nacional Patagónico (CENPAT-CONICET, Argentina) for overall assistance and logistic support. We also thank the Agencia Nacional de Investigación e Innovación (ANII, Uruguay) for supporting M.D. and V.F.-T with a Postdoctoral and PhD fellowship, respectively. The study was funded by the US Marine Mammal Commission under the order No. E4047335, the Fundación BBVA through the project 'Efectos de la explotación humana sobre depredadores apicales y la estructura de la red trófica del Mar Argentino durante los últimos 6.000 anos' (BIOCON 08 194/09 2009-2011), the Fundación Zoo Barcelona through the project 'Variables que afectan la dinámica poblacional del león marino sudamericano (Otaria flavescens) en las colonias reproductivas de Uruguay', the Agencia Nacional de Promoción Científica y Tecnológica (PICT $N^{\circ} 2110$ ), and the Zoo d'Amneville, France.

\section{LITERATURE CITED}

Alves-Stanley CD, Worthy GAJ (2009) Carbon and nitrogen stable isotope turnover rates and diet-tissue discrimination in Florida manatees (Trichechus manatus latirostris). J Exp Biol 212:2349-2355

Artico LO, Bianchini A, Grubel KS, Monteiro DS and others (2010) Mitochondrial control region haplotypes of the South American sea lion Otaria flavescens (Shaw, 1800). Braz J Med Biol Res 43:816-820

Beck CA, Bowen DW, McMillan JI, Iverson SJ (2003a) Sex differences in the diving behaviour of a size-dimorphic capital breeder: the grey seal. Anim Behav 64:1-13

Beck CA, Bowen WD, Iverson SJ (2003b) Sex differences in the seasonal patterns of energy storage and expenditure in a phocid seal. J Anim Ecol 72:280-291

Beck CA, Iverson SJ, Bowen WD, Blanchard W (2007) Sex differences in grey seal diet reflect seasonal variation in foraging behaviour and reproductive expenditure: evidence from quantitative fatty acid signature analysis. J Anim Ecol 76:490-502

Bligh EG, Dyer WJ (1959) A rapid method of total lipid extraction and purification. Can J Biochem Physiol 37: 911-917

Bocherens H, Grandal-d'Anglade A, Hobson KA (2014) Pitfalls in comparing modern hair and fossil bone collagen $\mathrm{C}$ and $\mathrm{N}$ isotopic data to reconstruct ancient diets: a case study with cave bears (Ursus spelaeus). Isotopes Environ Health Stud 50:291-299

Bond AL, Hobson KA (2012) Reporting stable-isotope ratios in ecology: recommended terminology, guidelines and best practices. Waterbirds 35:324-331

Breed GA, Bowen WD, McMillan JI, Leonard ML (2006) Sexual segregation of seasonal foraging habitats in a non-migratory marine mammal. Proc R Soc B 273: 2319-2326

Bugoni L, McGill RAR, Furness RW (2010) The importance of pelagic longline fishery discards for a seabird community determined through stable isotope analysis. J Exp Mar Biol Ecol 391:190-200

Bunn SE, Loneragan NR, Kempster MA (1995) Effects of acid washing on stable isotope ratios of $\mathrm{C}$ and $\mathrm{N}$ in penaeid shrimp and seagrass: implications for food-web studies using multiple stable isotopes. Limnol Oceanogr 40:622-625

Campagna C (1985) The breeding cycle of the southern sea lion, Otaria byronia. Mar Mamm Sci 1:210-218

Campagna C, Le Boeuf BJ (1988) Reproductive behaviour of southern sea lions. Behaviour 104:233-261

Campagna C, Werner R, Karesh W, Marin MR, Koontz F, Cook R, Koontz C (2001) Movements and locations at sea of South American sea lions (Otaria flavescens). J Zool 
(Lond) 255:205-220

Cappozzo HL, Perrin WP (2009) South American sea lion (Otaria flavescens). In: Perrin WF, Würsing B, Thewissen JGM (eds) Encyclopedia of marine mammals, 2nd edn. Academic Press, San Diego, CA, p 1076-1079

Clarke J, Manly B, Kerry K, Gardner H, Franchi E, Corsolini S, Focardi S (1998) Sex differences in Adelie penguin foraging strategies. Polar Biol 20:248-258

Clutton-Brock TH, Parker GA (1992) Potential reproductive rates and the operation of sexual selection. Q Rev Biol 67: 437-456

Clutton-Brock TH, Iason GR, Guiness FE (1987) Sexual segregation and density related changes in the habitat use in male and female red deer. J Zool (Lond) 211:275-289

Costa DP (1993) The relationship between reproductive and foraging energetics and the evolution of the Pinnipedia. In: Boyd IL (ed) Marine mammals: advances in behavioural and population biology. Oxford University Press, London, p 293-314

Costa DP (2008) A conceptual model of the variation in parental attendance in response to environmental fluctuation: foraging energetics of lactating sea lions and fur seals. Aquat Conserv Mar Freshw Ecosyst 17:S44-S52

Costa DP, Kuhn CE, Weise MJ, Shaffer SA, Arnould JPY (2004) When does physiology limit the foraging behaviour of freely diving mammals? Int Congr Ser 1275: 359-366

Crespo EA (1984) Dimorfismo sexual en los dientes caninos y en los cráneos del lobo marino del sur, Otaria flavescens (Pinnipedia, Otariidae). Rev Mus Argent Cienc Nat Bernardino Rivadavia Zool 13:245-254

Dalerum F, Angerbjörn A (2005) Resolving temporal variation in vertebrate diets using naturally occurring stable isotopes. Oecologia 144:647-658

DeNiro MJ, Epstein S (1978) Influence of diet on the distribution of carbon isotopes in animals. Geochim Cosmochim Acta 42:495-506

DeNiro MJ, Epstein S (1981) InfIuence of diet on the distribution of nitrogen isotopes in animals. Geochim Cosmochim Acta 45:341-351

Drago M, Cardona L, Crespo EA, Aguilar A (2009a) Ontogenic dietary changes in South American sea lions. J Zool (Lond) 279:251-261

Drago M, Crespo EA, Aguilar A, Cardona L, García N, Dans SL, Goodall N (2009b) Historic diet change of the South American sea lion in Patagonia as revealed by isotopic analysis. Mar Ecol Prog Ser 384:273-286

Drago M, Cardona L, Crespo EA, García N, Ameghino S, Aguilar A (2010) Change in the foraging strategy of female South American sea lions (Carnivora: Pinnipedia) after parturition. Sci Mar 74:589-598

Eder EB, Lewis MN (2005) Proximate composition and energetic value of demersal and pelagic prey species from the SW Atlantic Ocean. Mar Ecol Prog Ser 291:43-52

Fowler SL, Costa DP, Arnould JPY, Gales J (2007) Ontogeny of oxygen stores and physiological diving capability in Australian sea lions. Funct Ecol 21:922-935

Franco-Trecu V, Drago M, Riet-Sapriza FG, Parnell A, Frau $\mathrm{R}$, Inchausti $\mathrm{P}$ (2013) Bias in diet determination: incorporating traditional methods in Bayesian mixing models. PLoS ONE 8:e80019

Franco-Trecu V, Aurioles-Gamboa D, Inchausti P (2014) Individual trophic specialisation and niche segregation explain the contrasting population trends of two sympatric otariids. Mar Biol 161:609-618
Gentry RL, Costa DP, Croxall DP, David JP, Davis HM, Kooyman GL (1986) Synthesis and conclusion. In: Gentry RL, Kooyman GL (eds) Fur seals: maternal strategies on land and at sea. Princeton University Press, Princeton, NJ, p 220-278

Grandi MF, Dans SL, Crespo EA (2008) Social composition and spatial distribution of colonies in an expanding population of South American sea lions. J Mammal 89: 1218-1228

Hobson KA, Clark RG (1992a) Assessing avian diets using stable isotopes I: turnover of ${ }^{13} \mathrm{C}$ in tissues. Condor 94 : 181-188

Hobson KA, Clark RG (1992b) Assessing avian diets using stable isotopes II: factors influencing diet-tissue fractionation. Condor 94:189-197

Hobson KA, Schell DM, Renouf D, Noseworthy E (1996) Stable carbon and nitrogen isotopic fractionation between diet and tissues of captive seals: implications for dietary reconstructions involving marine mammals. Can J Fish Aquat Sci 53:528-533

Hückstädt LA, Rojas CP, Antezana T (2007) Stable isotope analysis reveals pelagic foraging by the Southern sea lion in central Chile. J Exp Mar Biol Ecol 347:123-133

Jackson AL, Parnell AC, Inger R, Bearhop S (2011) Comparing isotopic niche widths among and within communities: SIBER-Stable Isotope Bayesian Ellipses in R. J Anim Ecol 80:595-602

Jormalainen V, Honkanen $T$, Makinen A, Hemmi A, Vesakoski O (2001) Why does herbivore sex matter? Sexual differences in utilization of Fucus vesiculosus by the isopod Idotea baltica. Oikos 93:77-86

Kooyman GL (1989) Diverse divers: physiology and behavior. Springer-Verlag, Berlin

Kooyman GL, Castellini MA, Davis RW (1981) Physiology of diving in marine mammals. Annu Rev Physiol 43: 343-356

Kurle CM, Worthy GAJ (2001) Stable isotope assessment of temporal and geographic differences in feeding ecology of northern fur seals (Callorhinus ursinus) and their prey. Oecologia 126:254-265

Laws RM (1952) A new method of age determination for mammals. Nature 169:972-973

Layman CA, Arrington DA, Montanä CG, Post DM (2007) Can stable isotope ratios provide for community-wide measures of trophic structure? Ecology 88:42-48

Layman CA, Araujo MS, Boucek R, Hammerschlag-Peyer CM and others (2012) Applying stable isotopes to examine food-web structure: an overview of analytical tools. Biol Rev Camb Philos Soc 87:545-562

Le Boeuf BJ, Crocker DE, Costa DP, Blackwell SB, Webb PM, Houser DS (2000) Foraging ecology of northern elephant seals. Ecol Monogr 70:353-382

Lorrain A, Savoye N, Chauvaud L, Paulet Y, Naulet N (2003) Decarbonation and preservation method for the analysis of organic $\mathrm{C}$ and $\mathrm{N}$ contents and stable isotope ratios of low-carbonated suspended particulate material. Anal Chim Acta 491:125-133

Meynier L, Morel PCH, Chilvers BL, Mackenzie DDS, MacGibbon A, Duignan PJ (2008) Temporal and sex differences in the blubber fatty acid profiles of the New Zealand sea lion Phocarctos hookeri. Mar Ecol Prog Ser 366:271-279

Michener RH, Schell DM (1994) Stable isotope ratios as tracers in marine aquatic food webs. Blackwell, Oxford

Miller K, Irving L (1975) Metabolism and temperature regu- 
lation in young harbour seals, Phoca vitulina richardsi in water. Am J Physiol 229:506-511

Mysterud A (2000) The relationship between ecological segregation and sexual body size dimorphism in large herbivores. Oecologia 124:40-54

Nagy KA (1987) Field metabolic rate and food requirement scaling in mammals and birds. Ecol Monogr 57:111-128

Naya DE, Vargas R, Arim M (2000) Análisis preliminar de la dieta del león marino del sur (Otaria flavescens) en Isla de Lobos, Uruguay. Bol Soc Zool Urug 12:14-21

Newsome SD, Koch PL, Etnier MA, Aurioles-Gambao D (2006) Using carbon and nitrogen isotope values to investigate maternal strategies in northeast Pacific otariids. Mar Mamm Sci 22:556-572

Newsome SD, Clementz MT, Koch PL (2010) Using stable isotope biogeochemistry to study marine mammal ecology. Mar Mamm Sci 26:509-572

Oftedal OT, Boness DJ, Tedman RA (1987) The behavior, physiology, and anatomy of lactation in the Pinnipedia. In: Genoways HH (ed) Current mammalogy. Plenum Press, New York, NY, p 175-221

Page B, McKenzie J, Goldsworthy SD (2005) Dietary resource partitioning among sympatric New Zealand and Australian fur seals. Mar Ecol Prog Ser 293:283-302

Parnell AC, Inger R, Bearhop S, Jackson AL (2010) Source partitioning using stable isotopes: coping with too much variation. PLoS ONE 5:e9672

R Core Team (2013) R: a language and environment for statistical computing. R Foundation for Statistical Computing, Vienna, Austria. www.R-project.org

Riet Sapriza FG, Costa DP, Franco-Trecu V, Marín Y and others (2013) Foraging behavior of lactating South American sea lions, Otaria flavescens and spatial-resource overlap with the Uruguayan fisheries. Deep-Sea Res II 88-89:106-119

Riofrio-Lazo M, Aurioles-Gamboa D (2013) Timing of isotopic integration in marine mammal skull: comparative study between calcified tissues. Rapid Commun Mass Spectrom 27:1076-1082

Rosas FCW, Pinedo MC, Marmontel M, Haimovici M (1994) Seasonal movements of the South American sea lion (Otaria flavescens, Shaw) off the Rio Grande do Sul coast, Brazil. Mammalia 58:51-59

Rosen DAS, Trites AW (2000) Pollock and the decline of Steller sea lions: testing the junk-food hypothesis. Can J Zool 78:1243-1250

Ryan C, McHugh B, Trueman CN, Harrod C, Berrow SD, O'Connor I (2012) Accounting for the effects of lipids in stable isotope $\left({ }^{13} \mathrm{C}\right.$ and ${ }^{15} \mathrm{~N}$ values) analysis of skin and blubber of balaenopterid whales. Rapid Commun Mass

Editorial responsibility: Per Palsbøll, Groningen, The Netherlands
Spectrom 26:2745-2754

Sotiropoulos MA, Tonn WM, Wassenaar LI (2004) Effects of lipid extraction on stable carbon and nitrogen isotope analyses of fish tissues: potential consequences for food web studies. Ecol Freshw Fish 13:155-160

Soto KH, Trites AW, Arias-Schreiber M (2006) Changes in diet and maternal attendance of South American sea lions indicate changes in the marine environment and prey abundance. Mar Ecol Prog Ser 312:277-290

Staniland IJ, Boyd IL, Reid K (2007) An energy-distance trade-off in a central-place forager, the Antarctic fur seal (Arctocephalus gazella). Mar Biol 152:233-241

Thompson D, Duck CD, McConnell BJ, Garrett J (1998) Foraging behaviour and diet of lactating female southern sea lions (Otaria flavescens) in the Falkland Islands. J Zool (Lond) 246:135-146

Todd SK, Holm B, Rosen DAS, Tollit DJ (2010) Stable isotope signal homogeneity and differences between and within pinniped muscle and skin. Mar Mamm Sci 26:176-185

Vales DG, Saporiti F, Cardona L, De Oliveira LR and others (2014) Intensive fishing has not forced dietary change in the South American fur seal Arctophoca (=Arctocephalus) australis off Río de la Plata and adjoining areas. Aquatic Conserv Mar Freshw Ecosyst 24:745-759

Vaz-Ferreira R (1975) Behavior of the Southern sea lion Otaria flavescens (Shaw) in the Uruguayan Islands. Rapp P-V Reùn Cons Int Explor Mer 169:219-227

Vaz-Ferreira R (1982) Otaria flavescens (Shaw), South American sea lion. In: FAO, UNEP (eds) Mammals in the seas: small cetaceans, seals, sirenians and otters, Vol 4. FAO Fisheries Series 5:477-495

Wearmouth VJ, Sims DW (2008) Sexual segregation in marine fish, reptiles, birds and mammals: behaviour patterns, mechanisms and conservation implications. Adv Mar Biol 54:107-170

Werner R, Campagna C (1995) Diving behaviour of lactating southern sea lions (Otaria flavescens) in Patagonia. Can J Zool 73:1975-1982

Werner R, Figueroa-Carranza A, Ortiz CL (1996) Composition and energy content of milk from southern sea lions (Otaria flavescens). Mar Mamm Sci 12:313-317

Zenteno L, Crespo E, Goodall N, Aguilar A and others (2013) Stable isotopes of oxygen reveal dispersal patterns of the South American sea lion in the southwestern Atlantic Ocean. J Zool (Lond) 291:119-126

Zenteno L, Crespo E, Vales D, Silva L and others (2015) Dietary consistency of male South American sea lions (Otaria byronia) in southern Brazil during three decades inferred from stable isotope analysis. Mar Biol 162: 275-289

Submitted: May 27, 2014; Accepted: February 9, 2015 Proofs received from author(s): March 16, 2015 